\title{
The impacts of change in forage quality and seasonality on sheep farm profitability
}

\author{
R.W. WEBBY ${ }^{1}$ and G.W. SHEATH \\ AgResearch Ruakura, Private Bag 3123, Hamilton \\ ${ }^{1}$ webbyr@agresearch.cri.nz
}

\begin{abstract}
Systems planning tools were used to explore the benefits of altering the quality and seasonality of pasture supply in sheep farming enterprises. Three representative regions in New Zealand were studied; winter-cold and summer-wet (e.g., Southland, Otago and Central North Island); winter-cold, summer-dry (e.g., South Island East Coast); and winter-warm, summer-dry (e.g., North Island East Coast). Two different lamb-finishing enterprises were also analysed within each region; a conventional system where the lamb supply pattern was aligned with feed availability, and a supply contract system where more lambs were supplied for processing outside the normal season. Improving the seasonality of feed supply increased gross margins by $\$ 26$ to $\$ 126$ per hectare depending on the region. The greatest gains from improved seasonality occurred in the winter-cold scenarios. Improving forage quality had a more positive impact than improved seasonality changes with gross margins increasing by $\$ 53$ to $\$ 148$ per hectare depending on region. Overall the impact of the forage supply and forage quality changes was similar for the two lamb-finishing systems.
\end{abstract}

Keywords: lamb-finishing, pasture production, pasture quality, systems analysis

\section{Introduction}

The fine-tuning of farm systems to match the seasonal feed supply and maintain or improve feed quality is close to optimum in current New Zealand livestock systems (Webby 1993). However, the impact of further reducing the seasonality of forage supply, or improving forage quality throughout the year has not been quantified.

Our investigation explored the opportunities to improve the profitability of pasture-based sheep enterprises by improving either the seasonal supply of forage or the nutritive quality of the forage. How this can be achieved is briefly discussed, but the results of the analyses help to emphasise the direction for pasture plant breeding programmes and farm development in the future. The study focuses on the performance of a sheep enterprise and includes the adaptations of three lamb-finishing systems that can be related to the sheep farming regions of New Zealand. Included are simulations of supplying lambs to contracts outside the normal slaughter seasons.

\section{Methods}

The analyses were carried out using the Stockpol computer model (Marshall et al. 1991) and two spreadsheet models. They covered three regions that represent most of the sheep farming area of New Zealand (see climatic descriptions in Table 1).

Table 1 Climatic descriptions of the representative regions (longterm annual averages from the New Zealand Meteorological Service).

\begin{tabular}{lcccc}
\hline & $\begin{array}{c}\text { Sunshine } \\
\text { hours }\end{array}$ & $\begin{array}{c}10 \mathrm{~cm} \text { soil } \\
\text { temp }\left({ }^{\circ} \mathrm{C}\right)\end{array}$ & $\begin{array}{c}\text { Air } \\
\text { temp }\end{array}$ & $\begin{array}{c}\text { Rainfall } \\
\text { range }(\mathrm{mm})\end{array}$ \\
\hline Region 1 & 1595 & 9.0 & 9.7 & $900-1300$ \\
Region 2 & 1900 & 11.0 & 11.7 & $500-750$ \\
Region 3 & 1950 & 11.8 & 12.1 & $600-1000$ \\
\hline
\end{tabular}

Region 1: winter-cold, summer-wet e.g., Southland, Otago, Central NI

An intensive breeding and lamb-finishing system typical of Southland/Otago sheep-only farming was adapted to represent this region. The sheep breed used was Coopworth and rams joined the ewes on 20 April. The farm area was 200 ha and the supplementary feed was baled silage. For the contract supply analysis, all surplus ewe lambs and the lighter one-third of the male lambs were sold in June, July and August. The performance levels set (as modelled) are shown in Table 2. The forage supply assumed for Region 1 is shown in Figure 1 and annual pasture production was $12600 \mathrm{~kg} \mathrm{DM} / \mathrm{ha} /$ year.

Region 2: winter-cold, summer-dry e.g., SI East Coast A lamb-finishing system, typical of Canterbury dryland farming was adapted to represent this region. The dam breed was assumed to be Coopworth, with two-tooth ewes brought in as replacements. A Suffolk ram was used as a terminal sire joining the ewes on 17 March. The farm area was set at 300 ha and hay was the 
Table 2 Livestock performance for Region 1 (winter-cold, summer-wet).

\begin{tabular}{lccccr}
\hline System & $\begin{array}{c}\text { Stock } \\
\text { units } \\
\text { per ha }\end{array}$ & $\begin{array}{c}\text { Ewe } \\
\text { mating wt } \\
(\mathrm{kg})\end{array}$ & $\begin{array}{c}\text { Lamb } \\
\text { weaning wt } \\
(\mathrm{kg})\end{array}$ & $\begin{array}{c}\text { Lambing } \\
(\%)\end{array}$ & $\begin{array}{r}\text { Wool } \\
(\mathrm{kg} / \mathrm{ha})\end{array}$ \\
\hline Conventional & & & & & \\
Base & 15.8 & 65 & 31.8 & 130 & 94 \\
Seasonality & 15.8 & 70 & 33.9 & 144 & 102 \\
Quality & 15.8 & 70 & 33.9 & 144 & 105 \\
Contract & & & & & \\
Base & 17.5 & 65 & 31.9 & 130 & 77 \\
Seasonality & 18.0 & 70 & 33.9 & 144 & 81 \\
Quality & 18.0 & 70 & 33.9 & 144 & 81 \\
\hline
\end{tabular}

supplementary feed type. The contract system supplied lambs in October (where possible), November and December. On average lambs were supplied about 1 month earlier than the conventional system. The performance levels set are shown in Table 3 . The forage supply assumed for Region 2 is shown in Figure 1 and annual pasture production was $8000 \mathrm{~kg} \mathrm{DM} / \mathrm{ha} /$ year.

Table 3 Livestock performance for Region 2 (winter-cold, summer-dry).

\begin{tabular}{lccccc}
\hline System & $\begin{array}{c}\text { Stock } \\
\text { units } \\
\text { per ha }\end{array}$ & $\begin{array}{c}\text { Ewe } \\
\text { mating wt } \\
(\mathrm{kg})\end{array}$ & $\begin{array}{c}\text { Lamb } \\
\text { weaning wt } \\
(\mathrm{kg})\end{array}$ & $\begin{array}{c}\text { Lambing } \\
(\%)\end{array}$ & $\begin{array}{c}\text { Wool } \\
(\mathrm{kg} / \mathrm{ha})\end{array}$ \\
\hline $\begin{array}{l}\text { Conventional } \\
\text { Base }\end{array}$ & 10.4 & 60 & 30.0 & 130 & 45.6 \\
$\begin{array}{l}\text { Seasonality } \\
\text { Quality }\end{array}$ & 10.4 & 65 & 32.3 & 135 & 48.2 \\
Contract & 10.4 & 65 & 32.3 & 135 & 46.4 \\
$\begin{array}{l}\text { Base } \\
\text { Seasonality }\end{array}$ & 9.4 & 60 & 30.1 & 130 & 39.7 \\
Quality & 9.4 & 65 & 33.6 & 135 & 41.7 \\
\hline
\end{tabular}

\section{Region 3: winter-warm, summer-dry e.g., NI East Coast}

The system used was typical of a Hawke's Bay dryland lamb-finishing enterprise using a mix of breeds (Coopworth base) and the ram joining on 1 March. The farm area was set at 300 ha and the supplementary feed was baled silage. Lambs were supplied on contract in October, November and December. Sheep performance levels are described in Table 4. The forage supply for region 3 is shown in Figure 1 and annual pasture production was $10800 \mathrm{~kg} \mathrm{DM} / \mathrm{ha} /$ year.

Pasture growth data for each region were sourced from within the database of Stockpol (Lambert et al. 1984; Hayman \& McBride 1984; Radcliffe 1974 \& 1975 ) and the base forage supply for each representative farm was modified to:

a. Reduce the seasonality of forage supply: where distinct winter (May-August) and summer (December-February) production troughs existed,
Figure 1 Pasture growth profiles by region for base (-) and improved (- - ) seasonality scenarios.

Winter-cold, summer-wet Region 1

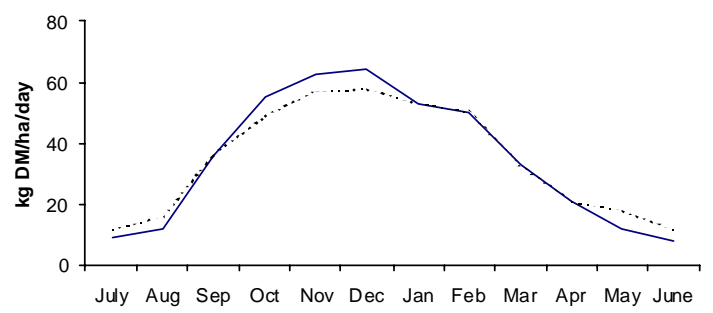

Winter-cold, summer-dry Region 2

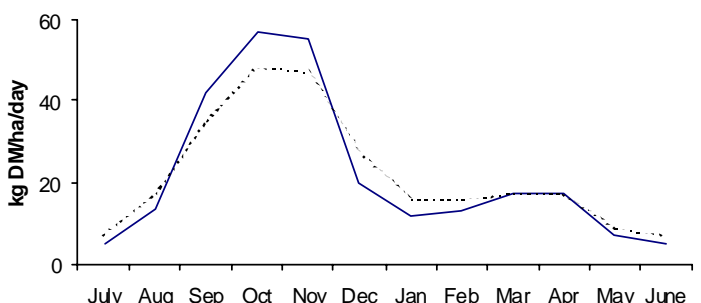

Winter-warm, summer-dry Region 3

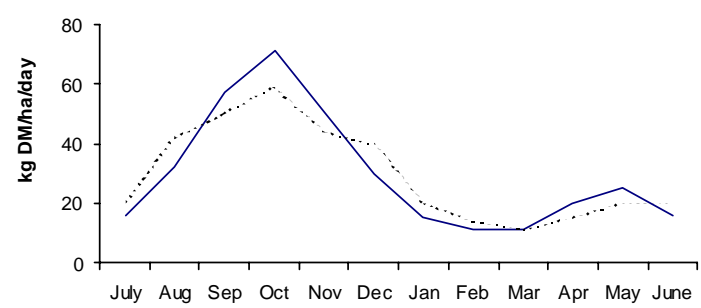

Table 4 Livestock performance for Region 3 (winter-warm, summer-dry).

\begin{tabular}{lccccc}
\hline System & $\begin{array}{c}\text { Stock } \\
\text { units } \\
\text { per ha }\end{array}$ & $\begin{array}{c}\text { Ewe } \\
\text { mating wt } \\
(\mathrm{kg})\end{array}$ & $\begin{array}{c}\text { Lamb } \\
\text { weaning wt } \\
(\mathrm{kg})\end{array}$ & $\begin{array}{c}\text { Lambing } \\
(\%)\end{array}$ & $\begin{array}{c}\text { Wool } \\
(\mathrm{kg} / \mathrm{ha})\end{array}$ \\
\hline Conventional & & & & & \\
Base & 11.9 & 65 & 25.9 & 133 & 44 \\
Seasonality & 11.9 & 65 & 25.9 & 133 & 44 \\
Quality & 11.9 & 70 & 28.4 & 144 & 46 \\
Contract & & & & & \\
Base & 11.9 & 65 & 21.8 & 133 & 43 \\
Seasonality & 11.9 & 65 & 21.8 & 133 & 43 \\
Quality & 11.9 & 70 & 24.3 & 144 & 45 \\
\hline
\end{tabular}

base pasture growth was increased by $33 \%$; and production during peak growth months was reduced to generate an annual production level similar to the base system.

b. Increase forage quality: the level and pattern of pasture growth of the base systems was retained, 
but the pasture quality patterns within Stockpol were assumed to increase from November to April over the base system. The increase was 1 Mega Joule (MJ) of metabolisable energy (ME) per kilogram of dry matter (kg DM) (Ulyatt et al. 1995) and the maximum value was limited to $11.5 \mathrm{MJ} \mathrm{ME} / \mathrm{kg}$ DM. This constraint was set to take into account the nutritive value (Wilman \& Riley 1993) of the alternative pasture species available.

The impact of changes to feed quality on lamb growth rate during lactation and lamb weaning weight were determined in a spreadsheet model developed by Woodward \& Webby (unpublished). Resulting ewe weights, lamb weights and weight gains were then reset in Stockpol. Changes to post-weaning lamb growth rates that were owing to changes in feed quality were measured using a second model developed by Woodward \& Webby (2000). This information was again used to adjust the liveweight gains in Stockpol.

The biological and financial impacts of altering the forage traits were determined for a conventional lamb supply system, and a contract supply system where a portion of the lamb crop was marketed earlier, or later than during the conventional supply seasons (e.g., in October-November or June-September). For the conventional system, the alignment of forage supply and demand was optimised by adjusting stocking rate, forage conservation and seasonal lamb supply pattern. The livestock systems used were derived to mirror those typically used within the regions involved. The approach taken was as follows:

a. For each region, the conventional system was established on the basis of the best gross margin (GM) achieved through the adjustment of stocking rate, lamb sale times, lamb carcass weights and the harvesting and feeding out of conserved feed.

b. From base system with stocking rate constant, and by modifying the parameters identified for the options in "a", above. Seasonality of feed supply was reduced, or feed quality was increased.

c. The base ewe mating weight, lambing percentage, and lamb weaning weight established for "a" above were adjusted for the seasonality and quality cases.

d. From the base in "a" above, in the contract supply systems, lamb sales were moved to before the start, and after of the main slaughter season, and then the same approach was taken as for "b" and "c" above. Seasonal price premiums for lambs in the contract supply system were defined for each region.

\section{Results}

Lamb carcass weights, value per head and farm gross margin for each scenario tested for all regions are summarised in Tables 5, 6 and 7. Changes in stocking rate, ewe-mating weight, lamb weaning weight, lambing percentage and wool produced per hectare are shown in Tables 2, 3 and 4.

Table 5 Mean lamb performance and financial summary for Region 1.

\begin{tabular}{|c|c|c|c|c|c|}
\hline System & $\begin{array}{c}\text { Ewe lamb carcass } \\
\text { wt }(\mathrm{kg})\end{array}$ & $\begin{array}{c}\text { Ewe lamb value } \\
(\$ / \text { head })\end{array}$ & $\begin{array}{l}\text { Ram lamb carcass } \\
\text { wt }(\mathrm{kg})\end{array}$ & $\begin{array}{l}\text { Ram lamb value } \\
\qquad(\$ / \text { head })\end{array}$ & $\begin{array}{c}\text { Farm gross } \\
\text { margin }(\$ / \mathrm{ha})\end{array}$ \\
\hline \multicolumn{6}{|c|}{ Conventional } \\
\hline Base & 14.6 & 41.36 & 17.4 & 48.51 & 797 \\
\hline Seasonality & 15.2 & 42.92 & 18.2 & 50.59 & 923 \\
\hline Quality & 17.4 & 47.78 & 18.3 & 50.35 & 944 \\
\hline \multicolumn{6}{|l|}{ Contract } \\
\hline Base & 17.7 & 64.72 & 17.7 & 54.52 & 739 \\
\hline Seasonality & 17.7 & 64.30 & 18.3 & 55.92 & 849 \\
\hline Quality & 17.1 & 62.55 & 19.0 & 57.93 & 863 \\
\hline
\end{tabular}

Table 6 Mean lamb performance and financial summary for Region 2.

\begin{tabular}{|c|c|c|c|c|c|}
\hline System & $\begin{array}{c}\text { Ewe lamb carcass } \\
\text { wt }(\mathrm{kg})\end{array}$ & $\begin{array}{l}\text { Ewe lamb value } \\
\qquad(\$ / \text { head })\end{array}$ & $\begin{array}{c}\text { Ram lamb carcass } \\
\text { wt }(\mathrm{kg})\end{array}$ & $\begin{array}{l}\text { Ram lamb value } \\
\qquad(\$ / \text { head })\end{array}$ & $\begin{array}{c}\text { Farm gross } \\
\text { margin }(\$ / h a)\end{array}$ \\
\hline \multicolumn{6}{|c|}{ Conventional } \\
\hline Base & 15.9 & 48.33 & 16.3 & 52.22 & 549 \\
\hline Seasonality & 16.7 & 50.53 & 17.2 & 54.91 & 626 \\
\hline Quality & 17.2 & 53.72 & 17.8 & 57.52 & 607 \\
\hline \multicolumn{6}{|l|}{ Contract } \\
\hline Base & 14.8 & 47.54 & 15.7 & 51.60 & 536 \\
\hline Seasonality & 16.1 & 51.44 & 17.5 & 56.82 & 609 \\
\hline Quality & 15.4 & 51.39 & 16.8 & 55.97 & 589 \\
\hline
\end{tabular}


Table 7 Mean lamb performance and financial summary for Region 3.

\begin{tabular}{|c|c|c|c|c|c|}
\hline System & $\begin{array}{l}\text { Ewe lamb carcass } \\
\text { wt }(\mathrm{kg})\end{array}$ & $\begin{array}{c}\text { Ewe lamb value } \\
(\$ / \text { head })\end{array}$ & $\begin{array}{c}\text { Ram lamb carcass } \\
\text { wt }(\mathrm{kg})\end{array}$ & $\begin{array}{l}\text { Ram lamb value } \\
\qquad \$ / \text { head })\end{array}$ & $\begin{array}{c}\text { Farm gross } \\
\text { margin (\$/ha) }\end{array}$ \\
\hline \multicolumn{6}{|c|}{ Conventional } \\
\hline Base & 15.3 & $\$ 45.67$ & 17.1 & $\$ 56.08$ & $\$ 587$ \\
\hline Seasonality & 15.3 & $\$ 45.67$ & 17.1 & $\$ 56.08$ & $\$ 629$ \\
\hline Quality & 16.8 & $\$ 54.11$ & 17.3 & $\$ 62.42$ & $\$ 712$ \\
\hline \multicolumn{6}{|l|}{ Contract } \\
\hline Base & 14.7 & $\$ 47.40$ & 16.3 & $\$ 57.69$ & $\$ 611$ \\
\hline Seasonality & 14.7 & $\$ 47.35$ & 16.3 & $\$ 57.19$ & $\$ 637$ \\
\hline Quality & 15.8 & $\$ 54.36$ & 17.4 & $\$ 62.30$ & $\$ 72$ \\
\hline
\end{tabular}

\section{Region 1}

The improved seasonality of pasture supply allowed ewe body weights to increase through lactation, thereby increasing lamb weaning weights by $2.1 \mathrm{~kg}$. It also allowed mating weight to increase to $70 \mathrm{~kg}$ and lambing percentage to improve from $130 \%$ to $144 \%$. These production increases were also achieved through improved pasture quality. In comparison gains of \$126 and $\$ 147 /$ ha above the base were estimated for the conventional improved seasonality and quality scenarios, respectively.

The higher stocking rate in the contract supply system is the result of the extra lambs being carried into the winter. In fact, ewe numbers were reduced from 2540 to 2329 with corresponding reduction in the number of ewe hogget replacements. With fewer ewes being wintered, gross margins were reduced (compared with conventional) by $\$ 58, \$ 74$ and $\$ 81 / \mathrm{ha}$ for the base, seasonality and quality contract scenarios, respectively.

\section{Region 2}

Improvement in seasonality and quality of pasture allowed ewe mating weight to increase by $5 \mathrm{~kg}$ and lambing percentage to increase by $5 \%$ for both the conventional and contract farms. Improved lamb carcass weights were worth an extra \$77/ha and \$58/ha for the improved pasture seasonality and quality, respectively. The base contract system did not perform as well as the base conventional (being $\$ 13 /$ ha less), but gains from the improved seasonality and quality were similar at $\$ 73$ and $\$ 53 /$ ha, respectively.

For the contract system, summer-autumn pasture cover was high $(2400 \mathrm{~kg}$ DM/ha) compared with $2040 \mathrm{~kg} \mathrm{DM} / \mathrm{ha}$ for the conventional system. This affected pasture recovery as a higher rate of decay function in Stockpol is activated when pasture cover exceeds $2200 \mathrm{~kg}$ DM/ha (Webby et al. 1995). The result was a lower cover going into the winter and one stock unit/ha less. This was despite the additional hay which was made in both the base contract farm and the quality contract farm (2500 and 3900 bales of hay respectively). These were sold and the income included in the GM as shown in Table 6 .

\section{Region 3}

No change in stocking rate was required for any of the Region 3 scenarios reflecting the good match existing between winter pasture growth rates and sheep feed demand. Improved seasonality for both the conventional and contract systems differed only from base in a lower requirement for silage. As a consequence, costs were lower and GMs increased by $\$ 42$ and $\$ 26 /$ ha through improved pasture seasonality for both the conventional and contract systems, respectively. However, for the improved quality scenarios the gains were much more substantial at $\$ 125$ and $\$ 110 /$ ha for both the conventional and contract system, respectively. These gains reflected a heavier ewe weight at weaning, a higher lamb weaning weight, a higher lambing percentage and higher lamb growth rates post weaning. The same amount of silage was made in both systems. In the contract system, where lambs were supplied on average 1 month earlier than the conventional system the GM improved by $\$ 24, \$ 8$ and $\$ 9 /$ ha for the base, seasonality and quality scenarios, respectively.

\section{Discussion}

Improving feed quality had the greatest effect on farm GM. For the winter-cool, summer-wet and winter-warm, summer-dry (Regions 1 and 3) cases where the advantages of better forage quality could be expressed most, increases in GM/ha ranged from \$110-\$148. Where forage quantity was a major constraint in both winter and summer (winter-cold, summer-dry, Region 2), the potential advantages of improved quality were not fully realised. In these cases reducing the degree of seasonality increased the GM/ha by approximately $\$ 70$.

These GM increases do not include any extra costs associated with improving forage seasonality or quality over-and-above the expenses already incurred in the base systems. Table 8 provides a guideline to the likely 
costs of pasture renewal given different methods of establishment, persistence and renewal frequency. All methods, where applicable, include one spray, seed, sowing, cultivation, rolling, harrowing and starter nitrogen, but not capital and maintenance fertiliser applications. Costs include an annual interest charge of $7 \%$ on the initial cost. The appropriate costs should be deducted from the GM gains to gauge the net benefit of improved seasonality or quality of forage supply.

Table 8 The annual costs (\$/ha sown) for different types and rates of pasture renewal.

\begin{tabular}{lccc}
\hline $\begin{array}{l}\text { Method of seed } \\
\text { bed preparation }\end{array}$ & $\begin{array}{c}\text { 20 year or } \\
\text { 5\%/year }\end{array}$ & $\begin{array}{c}10 \text { year or } \\
10 \% / \text { year }\end{array}$ & $\begin{array}{c}5 \text { year or } \\
\text { 20\%/year }\end{array}$ \\
\hline Cultivation & $\$ 71.40$ & $\$ 101.15$ & $\$ 160.65$ \\
Direct drilling & $\$ 53.28$ & $\$ 75.48$ & $\$ 119.88$ \\
Oversowing & $\$ 43.56$ & $\$ 61.71$ & $\$ 98.01$ \\
\hline
\end{tabular}

To achieve a net financial gain from improving seasonality in pasture supply or pasture quality, such extra costs would need to be less than $\$ 70-\$ 120 / \mathrm{ha} /$ year. Table 8 indicates that improved pasture would need to persist for at least 5 years, or produce considerably more feeding advantages than the figures used in these analyses. Stevens et al. (2000) showed that farm profitability increased substantially in Southland where new pasture performance peaked at 2 to 4 years; and the advantages over the original sward lasted for 10 to 14 years. Studies by Webby et al. 1990 and Barker et al. 1999 showed that new pasture species could be established to advantage in hill country. However, changes in seasonality of feed supply and feed quality do not necessarily have to occur through pasture improvement. Improved grazing management (Sheath et al. 1984), soil fertility (Gillingham et al. 1990) and subdivision (Fitzharris \& Wright 1984) can all contribute to less seasonality in pasture supply and improve feed quality. Financial analysis suggests that management and soil fertility must also be addressed in pasture improvement (Parminter 1991). One would assume that in any fine-tuned farm system these factors would not be an issue, leaving the opportunity for substantial gains to be made through pasture or forage supply improvement. Such improvements may include new pasture species, forage cropping, conservation and strategic supplementation with grain (Boom \& Sheath 1998, 1999; Drew \& Fennessy 1980).

\section{Conclusion}

Other than when large seasonality constraints exist, improving pasture quality will increase sheep farm performance and profitability significantly. New pasture cultivars that are developed will require agronomic traits that allow them to persist and retain their benefits for at least 5 to 7 years.

\section{ACKNOWLEDGEMENTS}

WoolPro for funding support of the analyses and the referees for their contribution to the manuscript.

\section{REFERENCES}

Barker, D.J.; Sheppard, D.G.; Mackay, A.D.; Dymock, N. 1999. Hill country farm investment options cocksfoot vs superphosphate fertiliser. Proceedings of the New Zealand Grassland Association 61: 1721.

Boom, C.J.; Sheath, G.W. 1998. Grain supplementation of finishing beef cattle. Proceedings of the New Zealand Society of Animal Production 58: 239242.

Boom, C.J.; Sheath, G.W. 1999. Tactical supplementation of beef finishing cattle. Proceedings of the New Zealand Society of Animal Production 59: 162-165.

Drew, K.R.; Fennessy, P.F. 1980. Eds, Supplementary feeding. New Zealand Society of Animal Production Occasional Publication No. 7.

Fitzharris, M.J.; Wright, D.F. 1984. Critical inputs into Gisborne hill country. Proceedings of the New Zealand Grassland Association 45: 27-37.

Gillingham, A.G.; Richardson, S.; Power, I.L.; Riley, J. 1990. Long term effects of withholding phosphate application on North Island hill country. Proceedings of the New Zealand Grassland Association 51: 11-16.

Hayman, J.M.; McBride, S.D. 1984. Winchmore Technical Report 17.

Lambert, M.G.; Trustrum, N.A.; Costall, D.A. 1984. The effect of slip erosion on seasonally dry Wairarapa hill pastures. New Zealand Journal of Agricultural Research 27: 57-64.

Marshall, P.R.; McCall, D.G.; Johns, K.L. 1991. Stockpol: A decision support model for livestock farms. Proceedings of the New Zealand Grassland Association 53: 137-140.

Parminter, T.G. 1991. Financial evaluation of hill country pasture improvement. Proceedings of the New Zealand Grassland Association 53: 117-121.

Radcliffe, J.E. 1974. Seasonal distribution of pasture production in New Zealand II. Southland plains. New Zealand Journal of Experimental Agriculture 2: 341-348.

Radcliffe, J.E. 1975. Seasonal distribution of pasture production in New Zealand VII. Masterton (Wairarapa) and Maraekakaho (Hawke's Bay). New 
Zealand Journal of Experimental Agriculture 3: 259-265.

Sheath, G.W.; Webby, R.W.; Pengelly, W.J. 1984. Management of late spring-early summer pasture surpluses in hill country. Proceedings of the New Zealand Grassland Association 45: 199-206.

Stevens, D.R.; Gibson, A.K.; Casey, M.J. 2000. Improving on-farm profitability of sheep and deer systems using pasture renewal in the southern South Island. Proceedings of the New Zealand Grassland Association 62: 201-205.

Ulyatt, M.J.; Lee, J.; Corson, D. 1995. Assessing feed quality. Ruakura Farmer's Conference Proceedings 47: 59-62.

Webby, R.W.; Sheath, G.W.; Boom, C.J. 1990. Performance of new pasture cultivars in a hill country finishing system. Proceedings of the New Zealand Grassland Association 51: 151-156.
Webby, R.W. 1993. Improving the balance of sheep and beef cattle livestock systems. Proceedings of the New Zealand Grassland Association 55: 73-76.

Webby, R.W.; McCall, D.G.; Blanchard, V.J. 1995. An evaluation of the Stockpol model. Proceedings of the New Zealand Society of Animal Production 55: 145-149.

Woodward, S.J.R.; Webby, R.W. 2000. A decision tool for calculating herbage mass and metabolisable energy requirements of growing cattle and sheep. Proceedings of the New Zealand Grassland Association 62: 13-18.

Wilman, D.; Riley, J.A. 1993. Potential nutritive value of a wide range of grassland species. Journal of Agricultural Science, Cambridge 120: 43-49. 